\title{
EFFECTS OF HYACINTH RESIDUES ON CHEMICAL PROPERTIES AND PRODUCTIVITY OF DEGRADED TROPICAL SOILS
}

\author{
P.C. Oguike and J.S.C. Mbagwu* \\ Department of Soil Science, University of Nigeria, Nsukka, Nigeria. \\ *E-mail: joembagwu2003@yahoo.com
}

\begin{abstract}
Water hyacinth (Eichhornia crassipes) is an aquatic weed that has blocked many havigable water-ways in the tropics. Attempts have heen made to control or erradicate it to no avail. Its capacity to produce large biomass in a short time could be explored to seek other ways of utilizing it as a biofertilises. An evaluation of the potentiat of water hyacinth (WH) residue as a biofertiliser was carried out in the greenhouse using a split-plot in a Rudomized Complete Block Design (RCBD) experiment with three replications of each treatment. Top soil samples taken from an Entisol, Lithic Usorthent. (S1) and an Ulisol, Typic Paleustult, (S2) constituted the main plot treatments, whereas the sub-plot treatments were control (C). inorganic fertilizer (N-P-K-Mg at the rates of $240,60,240$ and $80 \mathrm{~kg} / \mathrm{hat}$ (F), 20 tha water hyacinth (WHI), WHI + F, 40 tha water hyacinth (WH2). WH2 + F, WHI + 20 t tha rice mill waste $(W H I+R W 1), W H I+20$ tha poultry droppings (WHI + PDI) and WHI + 10 tha RW and 10 tha $P D(W H I+R W I+P D I)$. All amendments were mixed with the soils and incubated for 10 days before planting. The F treatment was applied at maize planting. Data were collected on maize performance and changes in soil chemical properties. Results showed that exchangeable cations, CEC, OC, total N, available $P$ and $p H$ increased in the WH-amended soils relative to the controls in both $S 1$ and $S 2$. The more fertile $S 1$ benefited from these amendments more than $S 2$ and showed that maize performance during the first cropping was better on SI than S2, whereas during the residual cropping the crop performed equally well on both soils. Lower maize dry matter yields occurred in the residuat than the first cropping. Also the less fertile $\$ 2$ had higher residual effect of the residues than S1. Generally. WH mixed with either PD or RW or both performed better than when used alone. These results indicate that WH has a lot of potential for use as a biofertilizer on these tow-fertile. fragile, tropical soils, especially if mixed with $P D$ or $P D+R W$.
\end{abstract}

Key words: Soil chemical properties; Soil tertility improvement: Maize pertomance: Water hyacinth residues; Poultry manure: Rice mill wastes: Nigeria.

\section{INTRODUCTION}

One of the important ways of improving soil nutrient status and enhancing continuous soil productivity is through the use of organic residues. Application of organic residues plays an important role in improving crop yields. To evaluate the agronomic potential of organic wastes on degraded soils, it is essential to consider the positive impact of their use on the chemical properties of such soils. For soils with good structure, improvements in the physical properties are not as primarily important as enhanced chemical properties due to organic waste application (Mbagwu et al., 1994).

Increase in the use of commercia! fertilizers had brought about improvements in crop yields (Obi and Molindo, 1995), though problems of soil acidity associated with this use became rampant (Obi and Akinsola, 1995; Blevins et al., 1983). Also increased use of inorganic fertilizers within developing countries posed a considerable financial problem in these areas (FAO, 1983), hence the need to explore other sources of soil amendment. Some of these sources include wastes from agriculture, industries, urban and domestic sewage and aquatic environment.

The aquatic environment is the most unexplored source of organic waste materials. Some weeds in this environment are obnoxious, constituting environmental nuisance. A typical example in the Nigerian aquatic environment is the water hyacinth (Eichhornia crassipes) which has persistently caused environmental problems in the coastal waters of Nigeria.

Within the sub-saharan Africa, investigations on the agronomic value of water hyacinth (WH) are scarce. Most of the information on the potential of this weed as a soil amendment had been obtained mainly from Asia where it was observed to improve crop yields due to enhanced nutrient status of the soils (Venkataramanan et ai., 1984; Utomo, 1981).

Water hyacinth suppresses other aquatic weeds as it forms green carpets on a large expanse of water surface Irrigation and drainage channels are clogged, hydroelectric installations are blocked and fisheries are seriously

(c) 2001 Faculty of Agriculture, University of Nigeria. $\stackrel{4}{\text { Nsukka }}$ 
affected whereever this weed invades (Rady, 1997). Other than the ordinary muisance, the WH poses some environmental health hazards by providing ideal breeding ground for mosquitoes, other kinds of insects and suails. These insects are carriers of diseases such as malaria and yellow fever. The snails are important in the life cycles of blood and liver flukes which are vectors of diseases such as schistosomiasis and fascioliasis (Rady, 1979).

The ability of WH to produce large biomass in a short time could be beneficial to mankind (Center and Durden, 1986; Kay and Haller, 1986; Rosemond et al., 1984; Haller and Tag El-Seed, 1977). The objective of this preliminary investigation was to characterize WH residue chemically and determine to what extent its use would improve the chemical properties and maize growth and yield on two degraded soils when it is used alone or combined with inorganic fertiliser, poultry manure and/or rice mill waste. It is hoped that the results of this study, if validated in the field, would help to solve the problems of use of the huge amounts of WH residues produced annually in Nigeria for crop produciion.

\section{MATERIALS AND METHODS}

\section{Sample Collection}

Top soil $(0-15 \mathrm{~cm})$ samples of a clay Entisol (Lithic Usorthent, S1) and a loamy sand Ultisol (Typic Paleustult, \$2) were used for this study. Both soils are degraded due to less than optimum soil physical and chemical properties (Mbagwu, 1992). Both soil samples and poultry droppings (PD) were collected from the University of Nigeria at Nsukka. Water hyacinth (WH) was collected from a lagoon within the Lagos area of Nigeria where it abounds and rice mill waste (RW) from Adani, near Nsukka. A focal variety of maize (Zea mays L..) was used as the indicator crop.

\section{Experimental Design}

The layout for this experiment was a split-plot in a Ran domized Complete Block Design (RCBD) with each treatment replicated three times. This investigation examined the influence of application rates of $\mathrm{WH}$, with and without inorganic fertilizer (F), RW and PM on soil chemical properties and on yield of maize. The soil samples (S1 and S2) were the main plot treatments whereas the amendments were the sub-plot treatments which were made up of the following:

(1) C........Control

(2) F........ Inorganic fertiliser, (N, P, K and $\mathrm{Mg}$ at 240 , 60,240 and $80 \mathrm{~kg} / \mathrm{ha}$, respectively)

(3) WH1.....20 t/ha water hyacinth residues

(4) WH1 +F..20 t/ha WH+inorganic fertilizer
(5) WH2 ....40 tha water hyacinth residues

(6) $\mathrm{WH} 2+F \ldots 40$ tha $W H+$ inorganic fertilizer

(7) $\mathrm{WH} 1+\mathrm{RW} 1 \ldots 20$ t/ha $\mathrm{WH}+20$ t/ha rice mill wastes (RW)

(8) WH1 + PD1 .. 20 t/ha WH +20 t/ha poultry droppings (PD), and

(9) WH1 +RW0.50+PD0.50..20 t/ha WH+10 t/ha $\mathrm{RW}+10 \mathrm{t} / \mathrm{ha} \mathrm{PD}$.

\section{Experimental Procedure}

The soil samples and the poultry droppings (PD) were air-dried at about $25^{\circ} \mathrm{C}$ and passed through a $2 \mathrm{~mm}$ sieve. The water hyacinth (WH) was cut to small pieces after oven-drying at $55^{\circ} \mathrm{C}$ for $48 \mathrm{~h}$. while $\mathrm{RW}$ which needed no sieving was also dry enough for the study.

In both experiments, WH (with or without conditionig with $F, R W$ and $P M$ ) was mixed with $2 \mathrm{~kg}$ of the soil samples and incubated at field capacity (FC) moisture content for 10 days in perforated $4 \mathrm{~kg}$-capacity clay pots. The incubation was needed to detoxify any harm ful materials produced during WH decomposition. Thereafter, eight (8) maize grains were planted per pot and thinned down to three (3), seven days after germination (7 DAG). Germination counts were taken daily from the first day of germination to the 7 th day, by which time germination had ceased in all the treat ments. Plant hieghts were recorded weekly from the 7 th day of germination for six (6) weeks at the end of which the plants were harvested. On each treatment dry matter yield of maize shoot was recorded in $g / p o t$. The second planing followed immediately using the same procedure as the tirst planting to ascertain the residual effects of WH (straight or mixed) treatments on maize growth and dry matter yields and on soil chemical properties.

\section{Laboratory Analyses}

Detailed chemical characterisation of the soil samples and WH, RW and PD were carried out by the methods of Anderson and Ingram (1993). The soil/amendment mixtures were air-dried after first cropping with careful removal of plant roots in preparation for laboratory analyses. These analyses included $\mathrm{pH}$ in $1: 2.5$ soil/ water ratio. Cation exchange capacity (CEC) was determined by the $\mathrm{NH}_{4} \mathrm{OAc}$ displacement method (Jackson, 1958) and exchangeable acidity by the titrimetric method after extraction with $1.0 \mathrm{M} \mathrm{KCl}$ (McLean, 1965). After extraction with neutral $\mathrm{NH}_{4} \mathrm{OAc}$ solution, the $\mathrm{Ca}$ and $\mathrm{Mg}$ in the leachate were determined by Atomic Absorption Spectrophotometry (AAS) whercas the $\mathrm{Na}$ and $\mathrm{K}$ were obtained by flame photometry. Total $N$ was determined by the macro Kjedahl digestion method (Bremner and Mulvaney, 1982) while OC was 
Table 1:Some chemical properties of the $0-20 \mathrm{~cm}$ of the two soils.

\begin{tabular}{|c|c|c|}
\hline \multirow[t]{2}{*}{ Property } & \multicolumn{2}{|c|}{ Value } \\
\hline & Entisol (S1) & Ultisol (S2) \\
\hline Sand $(\%)$ & 34.0 & 84.0 \\
\hline Silt $(\%)$ & 18.0 & 2.0 \\
\hline Clay $(\%)$ & 48.0 & 14.0 \\
\hline Texture & Clay & Loam saild \\
\hline $\mathrm{pH}\left(1: 2.5 \mathrm{H}_{2} \mathrm{O}\right)$ & 4.92 & 5.98 \\
\hline$O C(\%)$ & 2.07 & 0.20 \\
\hline Total N $(\%)$ & 0.18 & 0.02 \\
\hline Avail P (Bray II. ppm) & 14.7 & 7.36 \\
\hline $\mathrm{CEC}(\mathrm{Cmol}(+) / \mathrm{kg})$ & 7.0 & 3.0 \\
\hline \multicolumn{3}{|l|}{ Exch.bases $(\mathrm{Cmol}(+) / \mathrm{kg}$} \\
\hline $\mathrm{Na}$ & 0.04 & 0.05 \\
\hline K & 0.20 & 0.30 \\
\hline $\mathrm{Mg}$ & 1.40 & 0.40 \\
\hline $\mathrm{Ca}$ & 3.67 & 2.00 \\
\hline $\mathrm{Al}+\mathrm{H}$ & 1.00 & 0.60 \\
\hline Total Fe $(\%)$ & 10.93 & 2.64 \\
\hline Total Al $(\%)$ & 0.98 & 0.20 \\
\hline Total Mn (\%) & 0.013 & 0.003 \\
\hline $\mathrm{C} / \mathrm{N}$ ratic & 11.78 & 10.00 \\
\hline Saturation water $(\%)$ & 72.6 & 5.1 \\
\hline
\end{tabular}

measured by the Walkley and Black (1934) wet oxidation method and converted to OM by multiplying by 1.724. Available $P$ was determined by the Bray Il method of Bray and Kurtz (1945). These determinations were also made on the WH, RW and PD. Some of the characteristics of the soils are shown in Table 1. The characteristics of these amendements are given in Table 2 whereas the nutrients contained in each treatment are shown in Table 3.

Table 2: Some chemical properties of water hyacinth residue, rice mill waste and poultry droppings

\begin{tabular}{llll}
\hline Property & \multicolumn{3}{c}{ Value $^{1}$} \\
& WH & RW & PD \\
pH $\left(1: 10 \mathrm{H}_{2} \mathrm{O}\right)$ & 5.89 & 5.76 & 7.22 \\
OC $(\%)$ & 31.92 & 32.11 & 22.94 \\
Total $\mathrm{N}(\%)$ & 2.55 & 0.73 & 2.86 \\
Total $\mathrm{P}(\%)$ & 0.24 & 0.055 & 0.182 \\
Total $\mathrm{Mg}(\%)$ & 4.30 & 0.92 & 1.28 \\
Total $\mathrm{Na}(\%)$ & 0.43 & 0.20 & 0.35 \\
Total K $(\%)$ & 0.47 & 0.80 & 1.80 \\
Total Ca $(\%)$ & 0.16 & 1.08 & 2.56 \\
C:N ratio & 12.52 & 43.99 & 8.02 \\
C:P ratio & 13.30 & 58.38 & 12.60 \\
N:P ratio & 1.06 & 1.33 & 1.51 \\
\hline 1. WH = water hyacinth; $\mathrm{RW}=$ rice mill waste; \\
PD = poultry droppings.
\end{tabular}

\section{Data Analysis}

Measured data were analyzed according to the procedure for the split-plot in a Randomized Complete Block Design (RCBD) as outlined by Little and Hills (1978).
Table 3: Total amount of major nutrients $(\mathrm{mg} / \mathrm{kg}$ ) contained in each treatment.

\begin{tabular}{lcccccccc} 
Treatment & $\mathrm{N}$ & $\mathrm{Na}$ & $\mathrm{P}$ & $\mathrm{K}$ & $\mathrm{Mg}$ & $\mathrm{Ca}$ & $\mathrm{OC}$ \\
\hline Entisol (S1) & & & & & & & \\
$\mathrm{C}$ & 1800 & 9.20 & 7.36 & 78 & 168 & 734 & 20700 \\
$\mathrm{~F}$ & 1920 & 9.20 & 37.36 & 198 & 208 & 734 & 20700 \\
WH1 & 2055 & 52.2 & 31.36 & 125 & 598 & 750 & 23892 \\
WH1+F & 2175 & 52.2 & 61.36 & 245 & 638 & 750 & 23892 \\
WH2 & 2310 & 95.2 & 55.36 & 172 & 1028 & 766 & 27084 \\
WH2+F & 2430 & 95.2 & 85.36 & 292 & 1068 & 766 & 27084 \\
WH1+RW1 & 2128 & 72.2 & 36.86 & 205 & 690 & 830 & 27103 \\
WH1+PD1 & 2341 & 87.2 & 49.56 & 305 & 726 & 1290 & 26186 \\
WH1t & 2235 & 79.7 & 43.21 & 225 & 708 & 1060 & 26645 \\
RW0.5+ & & & & & & & \\
PD0.5 & & & & & & & \\
Ulisol (S2) & & & & & & & \\
C & 200 & 11.5 & 14.7 & 117 & 48 & 400 & 2000 \\
F & 320 & 11.5 & 44.7 & 237 & 88 & 100 & 2000 \\
WH1 & 455 & 54.5 & 38.7 & 164 & 478 & 416 & 5192 \\
WH1+F & 575 & 54.5 & 68.7 & 284 & 518 & 416 & 5192 \\
WH2 & 710 & 97.5 & 62.7 & 211 & 908 & 432 & 8384 \\
WH2+F & 830 & 97.5 & 92.7 & 331 & 948 & 432 & 8384 \\
WH1+RW1 & 528 & 74.5 & 44.2 & 244 & 570 & 496 & 8403 \\
WH1+PD1 & 741 & 89.5 & 56.9 & 344 & 606 & 956 & 7486 \\
WH1+ & 635 & 82.0 & 50.6 & 294 & 588 & 726 & 7945 \\
RW0.5+ & & & & & & & \\
PD0.5 & & & & & & & \\
\hline
\end{tabular}

The LSD test was used to detect differences between treatment means (Obi, 1988). The per cent dry matter yield increase over the control (Pl) was calculated for each treatment thus:

$$
\mathrm{PI}=(\mathrm{Ya} / \mathrm{Yc}-1) \times 100 \ldots
$$

where Ya is yield due to amendment and $Y c$ is yield in control.

The per cent reduction in yield during the second cropping over the first cropping (PR) was calculated as follows:

$$
P R=\{1-(Y s / Y f) \times 100\}
$$

where $Y f$ is yield during the first cropping and $Y s$ is yield during the second cropping. The per cent residual effect of the amendments during the second cropping (RE) is given as:

$$
R E=(Y s / Y f) \times 100 .
$$

where $\mathrm{Ys}$ and $\mathrm{Yf}$ are as defined in $\mathrm{Eq} .2$.

\section{RESULTS AND DISCUSSION}

\section{Changes in Soil Chemicai Properties}

\section{Soil Exchange Properties}

Application of WH increased the CEC and exchangeable bases of the two soils as shown in Table 4. The WH residue is an important source of these bases which contributed to the relatively high CEC of the soils. The S1 and $\mathbf{S} 2$ are dominated by kaolinite (a 1:1 clay mineral) (Mbagwu and Abeh, 1998). Therefore, the observed improvement in CEC was mainly due to increased OC 
Table 4: Exchange properties $(\mathrm{Cmol}(+) / \mathrm{kg})$ of two soils treated with organic and inorganic amendments.

\begin{tabular}{|c|c|c|c|c|c|c|c|}
\hline Soils & Treatments & $\mathrm{Na}$ & $K$ & $\mathrm{Mg}$ & Ca & $\mathrm{CEC}$ & $A 1+H$ \\
\hline Fintisol & $C$ & 0.17 & 0.06 & 0.6 & 3.7 & 6.5 & 1.0 \\
\hline \multirow[t]{8}{*}{$(S 1)$} & F & 0.13 & 0.80 & 0.6 & 3.3 & 7.0 & 1.0 \\
\hline & WHI & 0.20 & 1.20 & 0.8 & 4.7 & 80 & 0.6 \\
\hline & $W H 1+F$ & 0.17 & 1,10 & 0.8 & 3.9 & 85 & 0.8 \\
\hline & WH2 & 0.20 & 1.40 & 0.9 & 4.) & 95 & 0.6 \\
\hline & $W+2+F$ & 0.27 & 1.80 & 1.2 & 46 & 10.0 & 06 \\
\hline & $W H 1+R W I$ & 0.20 & 1.00 & 1.0 & 3.8 & 100 & 0.6 \\
\hline & WHI+PDI & 0.25 & 1.70 & 2.0 & 7.6 & 13.0 & 06 \\
\hline & $\begin{array}{l}\text { WHI }+R W 0.5+ \\
\text { PDO.5 }\end{array}$ & 0.17 & 1.00 & 3.5 & 3.1 & 80 & 0.6 \\
\hline \multirow[t]{2}{*}{ Means } & & 0.20 & 118 & 1.27 & 4.30 & 8.83 & 0.71 \\
\hline & $\mathrm{C}$ & 0.11 & 0.05 & 0.6 & 1.4 & 3.0 & 0.6 \\
\hline Ultisol & $\mathrm{F}$ & 0.11 & 0.30 & 0.5 & 1.3 & 3.0 & 0.6 \\
\hline \multirow[t]{7}{*}{$(S 2)$} & WHI & 011 & 0.40 & 0.7 & 1.6 & 4.0 & 0.6 \\
\hline & $W H I+F$ & 0.13 & 0.60 & 0.8 & 1.8 & 4.5 & 0.4 \\
\hline & WH? & 013 & 0.60 & 0.8 & 2.0 & 5.0 & 0.6 \\
\hline & $W+42 * F$ & 0.13 & 0.60 & 0.9 & 2.0 & 50 & 0.4 \\
\hline & WHI+RWI & 0.13 & 0.60 & 0.7 & 1.4 & 5.5 & 0.6 \\
\hline & WHII+PI)! & 011 & 0.40 & 0.6 & 3.5 & 0.5 & 0.4 \\
\hline & $\begin{array}{l}\text { WHI +RW0.5t } \\
\text { PDO0.5 }\end{array}$ & 010 & 0.40 & 1.4 & 22 & 8.0 & 0.6 \\
\hline Means & & 0.12 & 0.44 & 0,78 & 191 & 5.17 & 0.53 \\
\hline ISD & Soils (S) & 0,03 & 0.26 & 0.18 & 0.85 & 1.30 & 0.07 \\
\hline \multirow[t]{2}{*}{$(0.05):$} & Amendments & 0.01 & 0.07 & 0.14 & 0.23 & 0.46 & 0.03 \\
\hline & $\begin{array}{l}\text { (A) } \\
S \times A\end{array}$ & 0.01 & 0.08 & 0.12 & 0.27 & 0.47 & 0.03 \\
\hline
\end{tabular}

resulting from application of ordinary or nixed WH.

This was expected becat'se $O M$ more than inorganic clay colloids contributes to the CEC of soils that are low in OM and clay contents (Mbagwu et al., 1994: Asadu et al., 1997). The pH of the F treatment increased in $\mathrm{Sl}$ but decreased in $\mathrm{S} 2$ as shown in Table 5 . This result emphasizes the differential performance of inorganic fertilizer on soils and suggests that cortain characteristics of the soils may be implicated in this response. On both soils the highest increase in pH was obtained in the WH $1+$ PD 1 treatment, which implies that this treatnent which also had the highest amounts of $\mathrm{Ca}$ (Table 3). acted as a liming material in these soils.

The increased exchange properties were due to mineralization of applied WH residue with conscquent release of mutrients. In bolh soils, improvements in exchange properties reflected in the increasing rate of WH application. However, in SI for WH+F treatment. $\mathrm{Na}, \mathrm{K}, \mathrm{Ca}$ and CEC values were lower than those for the preceeding WH1 alone treatment. This trend also reflected in the exchangeable acidity $\left(\mathrm{Al}^{3+}+\mathrm{H}^{+}\right.$, which was higher in the WHI + H than WHI alone treatments. Perhaps, on the one hand, the inorganic fertilizer in this treatment might have induced slight increase in acidity which possibly affected microbial activities during mineralization, thus keeping the exchangeable bases low. On the other hand, the inorganic fertilizer might have induced more rapid mineralization, the nutrients of which were utilized by the maize plants as was suggested by Mbagwu (1992) and confirmed by the observed yield increases (Tables $6,7,8$, and 9).
Table 5: Residual $\mathrm{OC}$, total $\mathrm{N}$, available $\mathrm{P}$ and $\mathrm{pH}$ levels of the two soils treated with organic and inorganic amendments.

\begin{tabular}{|c|c|c|c|c|c|c|}
\hline Soils & Treatments & $\begin{array}{l}O C \\
(\%)\end{array}$ & $\begin{array}{l}\text { Avail P } \\
\text { (ppm) }\end{array}$ & $\begin{array}{l}\text { Total } \\
(\%)\end{array}$ & $N$ & $\mathrm{pH}\left(\mathrm{H}_{2} \mathrm{O}\right)$ \\
\hline Entisol & C & 2.51 & 4.8 & 0.21 & & 4.97 \\
\hline \multirow[t]{10}{*}{ S1) } & $F$ & 2.83 & 9.7 & 024 & & 5.07 \\
\hline & WH1 & 3.19 & 17.7 & 0.27 & & 5.34 \\
\hline & $\mathrm{WHI}+\mathrm{F}$ & 2.91 & 17.7 & 0.26 & & 5.18 \\
\hline & WH2 & 2.95 & 27.4 & 0.26 & & 5.19 \\
\hline & $\mathrm{WH} 2+\mathrm{F}$ & 3.23 & 32.2 & 0.28 & & 5.17 \\
\hline & WHI+RWI & 2.55 & 64.4 & 0.23 & & 8.40 \\
\hline & WH1+PD1 & 3.43 & 16.1 & 0.28 & & 6.04 \\
\hline & WHIt+ & & & & & \\
\hline & RW0.5+ & & & & & \\
\hline & PD0.5 & 3.59 & 27.4 & 0.31 & & 5.74 \\
\hline Means & & 3.02 & 24.4 & 0.26 & & 5.34 \\
\hline Ultisol & C & 0.36 & 6.4 & 0.036 & & 599 \\
\hline \multirow[t]{9}{*}{$(\$ 2)$} & $\mathrm{F}$ & 0.32 & 9.7 & 0.033 & & 586 \\
\hline & WHI & 0.64 & 24.4 & 0.068 & & 6.71 \\
\hline & $W H I+F$ & 0.72 & 29.0 & 0.068 & & 6.22 \\
\hline & WH2 & 0.64 & 37.0 & 0.068 & & 6.55 \\
\hline & $\mathrm{WH} 2+\mathrm{F}$ & 0.56 & 38.6 & 0.055 & & 6.25 \\
\hline & $W H 1+R W l$ & 1.08 & 25.8 & 0.095 & & 6.20 \\
\hline & WHI+PD1 & 0.84 & 120.8 & 0.080 & & 6.77 \\
\hline & WHI+ & & & & & \\
\hline & RW0.5+ & 064 & & 0060 & & 624 \\
\hline \multirow{2}{*}{\multicolumn{2}{|c|}{$\begin{array}{l}\text { Means } \\
\operatorname{LSD}(0.05) \text { : }\end{array}$}} & $\begin{array}{l}0.04 \\
0.64\end{array}$ & $\begin{array}{l}20.4 \\
38.7\end{array}$ & 0.062 & & 6.31 \\
\hline & & & & & & \\
\hline \multicolumn{2}{|c|}{ Soils (S) } & 1.68 & 10.2 .5 & 0.140 & & 0.69 \\
\hline \multicolumn{2}{|c|}{ Amendments $(A)$} & 0.11 & 9.13 & 0.010 & & 0.10 \\
\hline \multicolumn{2}{|l|}{$S x A$} & 0.42 & 9.14 & 0.030 & & 0.18 \\
\hline
\end{tabular}

Similarly, when WH was mixed with PD in S2 it did not improve the exchangeable $\mathrm{Na}$ content and also decreased exchangeable $\mathrm{K}$ and $\mathrm{Mg}$. Furthermore, as was the case with $\mathrm{WH}+\mathrm{F}$ treatment in S1, probably, there was rapid mineralization with consequent utilization of released nutrients by the maize crop as reflected in yield increases shown in Tables 6, 7, 8 and 9. Mbagwu (1992) had shown that RW and PM had rapid mineralization rates $(0.00189$ and 0.00297 per day, respectively) which would ensure that where they are mixed with $\mathrm{WH}$, improvements in mineralization rate of WH would result.

Improvements in exchangeable properties of soils due to organic residue application were also reported by Mbagwu (1992). With application of WH on the acidic S1, exchangeable acidity decreased relative to the control, possibly due to removal of $\mathrm{Al}^{+}$from the soil exchange sites by $\mathrm{OM}$ from decomposing WH. This agrees with the observations of Hargrove and Thomas (1981). The reduction may also be due to the neutralization of $\mathrm{Al}^{\hat{3}+}$ by $\mathrm{Ca}$ and $\mathrm{Mg}$ released by the decomposing $\mathrm{WH}$ residues as observed with other decomposing wastes (Mbagwu et al., 1994).

\section{Changes in $\mathrm{OC}$, total $\mathrm{N}$ available $\mathrm{P}$ and $\mathrm{pH}$}

Increasing rates of mixed or straight $W H$ in both soils improved their $O C$, total $N$ and available $P$ relative to 
Table 6: Influence of organic and inorganic fertilizer on maize performance on two soils during the first cropping.

\begin{tabular}{|c|c|c|c|c|c|c|c|c|c|}
\hline \multirow[t]{2}{*}{ Trts $^{1}$} & \multicolumn{3}{|c|}{ Germination $(\%)$} & \multicolumn{3}{|c|}{ Plant height $(\mathrm{cm})$} & \multicolumn{3}{|c|}{$\mathrm{DMY}^{2}(\mathrm{~g} / \mathrm{pot})$} \\
\hline & S1 & $\mathrm{S} 2$ & Mean & SI & $\mathrm{S} 2$ & Mean & SI & $\mathrm{S} 2$ & Mean \\
\hline $\mathrm{C}$ & 95.8 & 87.5 & 91.7 & 22.5 & 23.7 & 23.1 & 2.64 & 1.96 & 2.30 \\
\hline $\mathrm{F}$ & 95.8 & 91.7 & 93.8 & 33.7 & 30.5 & 32.1 & 5.08 & 3.50 & 4.29 \\
\hline WH! & 95.8 & 83.3 & 89.6 & 48.3 & 46.9 & 47.6 & 12.04 & 7.17 & 9.61 \\
\hline $\mathrm{WH} 1+\mathrm{F}$ & 87.5 & 83.3 & 85.4 & 54.7 & 45.9 & 50.3 & 14.71 & 7.60 & 11.12 \\
\hline WH2 & 87.5 & 91.7 & 89.6 & 540 & 45.4 & 49.7 & 14.17 & 8.33 & 11.25 \\
\hline WH2+1: & 83.3 & 95.8 & 89.6 & 534 & 36.0 & 44.7 & 12.73 & 8.46 & 10.60 \\
\hline WH1+RW1 & 87.5 & 91.7 & 89.6 & 51.8 & 35.9 & 43.9 & 10.69 & 6.60 & 8.65 \\
\hline WH1+PDI & 958 & 958 & 95.8 & 529 & 42.5 & 47.2 & 13.17 & 8.49. & 10.83 \\
\hline WH1 + RW0.5+ PD0.5 & 75.0 & 95.8 & 85.4 & 51.0 & 40.5 & 45.7 & 13.00 & 6.63 & 9.82 \\
\hline Mean & 89.3 & 90.7 & - & 46.9 & 38.6 & - & 10.91 & 6.53 & - \\
\hline $\operatorname{LSD}(0.05)$ & & & & & & & & & \\
\hline Soils(\$) & NS & & & 5.11 & & & 3.16 & & \\
\hline Amendments (A) & 10.2 & & & 8.09 & & & 1.97 & & \\
\hline $\mathrm{SxA}$ & NS & & & NS & & & 2.65 & & \\
\hline
\end{tabular}

Table 7: Influence of organic and inorganic fertilizer on maize performance on two soils during the second cropping.

\begin{tabular}{|c|c|c|c|c|c|c|c|c|c|}
\hline \multirow[t]{2}{*}{ Trts $^{1}$} & \multicolumn{3}{|c|}{ uermination $(\%)$} & \multicolumn{3}{|c|}{ Plant height $(\mathrm{cm})$} & \multicolumn{3}{|c|}{$\mathrm{DMY}^{2}(\mathrm{~g} / \mathrm{pot})$} \\
\hline & Sl & $\$ 2$ & Mean & $S 1$ & $\$ 2$ & Mean & $\mathrm{Sl}$ & $\mathrm{S} 2$ & Mean \\
\hline C & 75,0 & 91.7 & 83.3 & 20.1 & 24.3 & 22.2 & 2.26 & 1.62 & 1.94 \\
\hline $\mathrm{F}$ & 75.0 & 91.7 & 83.3 & 19.1 & 26.4 & 22.8 & 1.96 & 1.89 & 1.93 \\
\hline WH! & 87.5 & 87.5 & 87.5 & 24.8 & 30.9 & 27.8 & 3.43 & 3.49 & 3.46 \\
\hline $\mathrm{WHI}+\mathrm{F}$ & 66.7 & 100.0 & 83.3 & 26.3 & 284 & 27.3 & 3.75 & 3.68 & 3.72 \\
\hline WH2 & 87.5 & 91.7 & 89.6 & 29.8 & 32.6 & 31.2 & 4.77 & 4.65 & 4.71 \\
\hline $\mathrm{WH} 2+\mathrm{F}$ & 79.2 & 95.8 & 87.5 & 32.2 & 29.4 & 30.8 & 5.16 & 4.18 & 4.64 \\
\hline $\mathrm{WH} 1+\mathrm{RWl}$ & 100.0 & 91.7 & 958 & 35.7 & 37.6 & 36.6 & 4.53 & 3.52 & 4.03 \\
\hline WHI+ PDI & 100.0 & 91.7 & 95.8 & 44.9 & 39.9 & 42.4 & 6.70 & 5.13 & 5.92 \\
\hline WHI + RW0.5+PDO 0.5 & 100.0 & 91.7 & 95.8 & 441 & 37.8 & 40.9 & 5.52 & 4.39 & 4.96 \\
\hline Mean & $85.7 \cdot$ & 92.2 & - & 30.8 & 31.9 & - & 4.23 & 3.62 & - \\
\hline $\operatorname{LSD}(0.05)$ & & & & & & & & & \\
\hline Soils(S) & 5.06 & & & NS & & & 0.38 & & \\
\hline Amendments (A) & 4.93 & & & 3.25 & & & 0.52 & & \\
\hline $\mathrm{SxA}$ & $N S$ & & & NS & & & NS & & \\
\hline
\end{tabular}

Table 8: Dry matter yield increase (\%) over the control and reduction during the second cropping (\%) following organic and inorganic amendments.

\begin{tabular}{lcccccc}
\hline Trt $^{1}$ & First cropping & Second cropping & Per cent reduction \\
\hline C & S1 & S2 & S1 & S2 & S1 & S2 \\
F & - & - & - & - & 14.4 & 17.3 \\
WH1 & 92.4 & 78.6 & -13.3 & -16.7 & 61.4 & 46.0 \\
WH1+F & 356.1 & 265.8 & 51.8 & 115.4 & 71.5 & 51.3 \\
WH2 & 457.2 & 287.8 & 65.9 & 127.2 & 74.5 & 51.6 \\
WH2+F & 436.7 & 325.0 & 111.1 & 187.0 & 66.3 & 44.2 \\
WH1+RW1 & 382.2 & 331.6 & 128.3 & 158.0 & 59.5 & 49.8 \\
WH1+PD1 & 304.9 & 236.7 & 100.4 & 117.3 & 57.6 & 46.7 \\
WHI+RW0.5+ PD0.5 & 398.9 & 333.2 & 96.5 & 216.7 & 49.1 & 39.6 \\
Mean & 392.4 & 238.3 & 144.2 & 204.3 & 57.5 & 33.8 \\
LSD (0.05) & 352.6 & 262.1 & 98.1 & 138.7 & 56.9 & 42.3 \\
\hline
\end{tabular}

1. As explained in the text. $\mathrm{S1}=$ Entisol; $\mathrm{S2}=$ Ultisol.

the control (Table 5). In comparison to that before planting, $\mathrm{pH}$ increased in both soils with WH application, although no significant differences were observed helween the values of these treated soils and the control. The $F$ treatment recorded the least value in both soils, a trend that was also observed in exchangeable acidity (Table 4 ). The highest increases in these proper. ties occurred when WH was mixed with RW and PD. This shows that mixing WH with these agricultural wastes improved these soil parameters more than increasing the application rate of $\mathrm{WH}$.

Relative to the control, improvements in $\mathrm{OC}$ and 
total $\mathrm{N}$ were higher on the Ultisol (S2) than on the Entisol ( $\mathbf{S 1}$ ) because $\mathbf{S 1}$ contains higher levels of these nutrients (Table 5). Improvements in $\mathrm{OC}$ in $\mathrm{S} 1$ and $\mathrm{S} 2$ over the controls were $43 \%$ and $20 \%$, respectively, and in total $\mathrm{N}, 47.6 \%$ and $163.9 \%$, respectively. For similar reasons, relative improvements in available $P$ and soil $\mathrm{pH}$ levels were higher on S1 than S2. This observation corroborates similar findings by Mbagwu et al. (1994), Mbagwu et al. (1991), Mbagwu and Piccolo (1990) and Bernal et al. (1992) who used organic residues from other sources as soil amendments.

\section{SOIL PRODUCTIVITY}

\section{Maize Germination}

As shown in Tables 6 and 7, the average percent germinations of 89.3 and 90.7 in S1 and S2, respectively during the first cropping and 85.7 and 92.2 , respectively during the second cropping were very good. However, they contrasted with an earlier study by Ahmed et al. (1982) in which they observed that germination and growth of raddish seedlings were inhibited by aqueous extracts of WH leaves and rhizomes. This may imply that using dehydrated WH is better than using the aqueous extracts of WH leaves and rhizomes as biofertilizers. During the second cropping, shown in Table 7, no regular pattern was observed in the germination count in $\mathrm{S} 1$ and during both croppings in $\mathrm{S} 2$.

On $\mathrm{S} 2$ the residual cropping was better than the first by only $1.7 \%$ in germination count while on $\mathrm{S} 1$ the first cropping was better than the residual cropping by $4.2 \%$ (Tables 6 and 7). Generally, germination was very good on both soils since these differences are not significant. However, there was significant difference $(P<0.05)$ between the two soils during the second cropping (Table 7). The $S 2$ performed better than $S 1$ because $S 2$ is generally better aerated because of its sandy texture (Table 2).

The effects of WH mixed with RW and PD on maize performance are also shown in Tables 6 and 7. No sequential order in germination was observed on S1 during the first cropping and differences were not significant at $\mathrm{P}<0.05$. During the residual cropping on the same $\mathrm{S} 1$, all treatments but the control $(75 \%)$ had $100 \%$ germination. On S2, during the first and residual croppings, no significant effects were observed on germina. tion counts. Although WH amendment did not outperform the control in germination, it neither retarded nor inhibited germination.

\section{Crop Growth}

Water hyacinth $(\mathrm{WH})$ residues stimulated maize growth as was observed during plant height measurements shown in Tables 6 and 7. Similar results were recorded by others (Roy, 1979; Chakraverty, 1984; Utomo, 1981). Overall, the tallest plant of $54.7 \mathrm{~cm}$ at harves was recorded in the $\mathrm{WHI}+\mathrm{F}$ treatment during the first cropping while the shortest one of $19.1 \mathrm{~cm}$ was observed in the $\mathrm{F}$ treatment during the second cropping (Tables 6 and 7).

In mixing WH with RW and PD also shown in Tables 6 and 7, there were no observable regular patterns in plant heights in both soils, though all treatments performed better than the controls during both croppings. Generally, there were significant treatment effects $(\mathrm{P}<0.05)$ in all cases, even though the $F$ and control treatments had similar heights. No significant interactions were observed in all cases but there was significant difference between the soils, with S1 outperforming S2 during the first cropping (Table 6). This implies that the effect of WH on maize growth is soil-specific. In all these cases, except for the increasing rates of WH during the second cropping (Table 7), the tallest plants were observed on S1 which is more fertile than S2 (Table 3).

\section{Dry Matter Yield of Maize Shoots}

Maize shoot dry matter yields were better on the more fertile S1 than S2 (Tables 6 and 7). With increasing rate of WH, there was no significant difference between the two soils during the second cropping. In all other cases, there were significant differences $(P<0.05)$ in dry matter yields between the two soils. The treated soils (except F) performed significantly better than the controls. However, during the first cropping, the $\mathrm{F}$ treatment on $\mathrm{S}$ l was lower than the other treatments but slightly higher than the control. There was no observa ble sequence in improvements in yield over the control as WH rates increased during the first cropping. Here, the highest yield was obtained in $\mathrm{WH}+\mathrm{F}$ treatment. During the second cropping, increases in maize dry matter yields with increased rate of WH reflected a regular pattern on $\mathrm{S} I$ except on the $\mathrm{F}$ treatment which performed less than the control. Here, the highest yield was observed in the $\mathrm{WH} 2+\mathrm{F}$ treatment. The less fertile S2 reflected a near complete regular pattern of yield increases over the control as the treatment rates increased during both the first and second croppings.

Using WH mixed with RW and PD during the first cropping in the two soils did not give as much dry matter yield as with increasing rates of WH although there were significant yield increases over the control. The WHI + PD treatment recorded the highest yield on both soils during the two croppings. These improvements in yields were most likely as a result of enhanced nutrient status of the soils due to the WH amendments (Table 3 ). Similar results were observed by Mbagwu et al. (1994) when they used dehydrated swine waste to improve the productivity of similar soils. Also Chakraverty (1984), 
Table 9: Estimate of residual effect $(\%)$ of water hyacinth conditioned with inorganic fertilizer, rice mill waste and poultry dropping on two degraded soils in Nigeria.

\begin{tabular}{|c|c|c|}
\hline Amendments & Sl (Entisol) & $S 2$ (l!ltisnl) \\
\hline$C$ & 85.6 & 82.7 \\
\hline$\Gamma$ & 38.6 & 54.0 \\
\hline WHI & 28.5 & 48.7 \\
\hline$W H+F$ & 25.5 & 48.4 \\
\hline$W ! 12$ & 33.7 & 55.8 \\
\hline$W H Z+F$ & 40.5 & 49.4 \\
\hline WH1+RW1 & 42.4 & 53.5 \\
\hline$W H 1+P D !$ & 50.9 & 604 \\
\hline WHit KW0.5+PDO 5 & 4.7 & 66.2 \\
\hline Mean & 43.2 & 5.7 .7 \\
\hline$L S D(0.05)$ & 4.2 & 2.6 \\
\hline
\end{tabular}

Mohan (1984), Kondap et al. (1981) and Utomo (1981) recorded yield increases with WH as soil amendment. Lower yields on F reatments in comparison to others (except the control) may be due to the incapacity of the inorganic fertilizer to amcliorate degraded soil physical properties as well as low nutrient status of soils treated with inorganic fertilizer (Table 3 ).

The WH might have released some organic compounds (especially polysaccharides and microbial gums) during decomposition and mineralization which were capable of improving degraded soil physical and chemical fertility (Spaccini et al., 2002). Although two limes the locally recommended rate of inorganic fertilizer for maize production was used in this study, the results have shown that there is still need for addition of organic amendments to improve the chemical properties of these degraded soils.

The per cent dry matter increases over the control shown in Table 8 indicated that increases were higher on $\mathrm{S1}$ than $\mathrm{S} 2$ during the first cropping whereas $\mathrm{S} 2$ recorded higher yield increases over the control than $\mathrm{S} 1$ during the residual cropping. This meant that the residual effect of WH (Table 9) was more obvious on the less fertile $S 2$ than $S 1$. Except for the control, the per cent yield reduction during the residual cropping in both soils was higher in the more fertile S1 than S2. It also indicated higher residual effect due to WH on $\mathrm{S} 2$ than $S 1$. These results may be explained by the higher inherent fertility of SI than S2.

\section{CONCLUSION}

The following conclusions can be drawn from these results: (1) Water hyacinth (WH) is a useful soil amendment; (2) It performs best when mixed with rice mill waste and poultry droppings; (3) The essential plant nutrients contained in WH are released during mineralization to the extent that they supported plant growth; and (4) Optimum rate of application for maximum maize yield is soil-dependent but when conditioned with PD, lower rates of about 20 tha produced more yields than higher rates. It is suggested that such a study be carried out in the field to validate these greenhouse results.

\section{REFERENCES}

Anderson. J.M, and Ingram, J.S.I. (Eds.) 1993. Tropical Soil Biology and Fertility Handbook of Methods 2nd ed. $\mathrm{CAB} 3$ International. UK.

Ahmed, S.A. Itom, M. and Ueki, K. (1982). Phytotoxic effect of water lyacinth water extract and decayed residue, Weed Research. Japan. 27: 117-183.

Asãdu. C.L.A. Diels, J. \& Vanluawe. B. 1997. A comparison of the contributions of clay, silt and organic natter to the effective CEC of soils in sub-saharan Africa. Soil Sci. 162: 785-794.

Bernal. M.P. Roig. A.. Lax. A. and Navarro, A.F. (1992). Effects of the application of pie slurry on some physico-chemical and physical properties of calcerous soils. Biores. Technol. 42: 233-239.

Blevins. R.L.. Smith, M.S., Thomas, G.W. and Frye. W.W. (1983). Influence of conservation tillage on soil properties. J. Soil Water Conserv. 38: 301-305.

Bray, R.H. and Kurtz, L.T. (1945). Determination of total. organic and available forms of phosphorus in soils. Soil Sci. 59: 39-45.

Bremer. J.M. and Mulvaney. C.S. (1982). Nitrogen - total. In: Methods of Soil Analysis. Part 2, 2nd ed., A.I. Page et al. (Eds.), pp. 595-624. ASA; SSSA. Madi-son. Wisconsin.

Center. J.D. and Durden. W.C. (1986). Variation in warer hydcintly/weevil interactions resulting from temporal differences in weed controi efforts. J. Aquatic Plant Manage. 24: 28-38.

Charudattan. R. (1984). Role of Cercospora rodomanii and other pathogens in the biological and intergrated controls of water hyacnth. In: Proceedings of the International Conference on Water Hyacinth. Ed. Thyagarajan. G. UNEP. Nairobi. Kenya. pp. 834859.

FAO (1983). The State of Food and Agriculture. In: FAO World Review. No. 16. pp. 21-22. FAO Publications. Rome.

Haller, W.T. and Tag EI Seed. M. (1979). Study of water hya cinths showing possible resistance of 2,4-D chemical control programs. Miscellaneous Publication. US Army Engineer Waterways Experiment Station No. WESMP-A-79-8. $18 \mathrm{pp}$.

Hargrove. N.L. and Thomas. G.W. (1981). Effect of organic matter on exchangeable aluminium and plant growth in acid soils. ASA Special Publication No. 4.. Madison. Wisconsin. pn. 151-166.

Jackson. M.C. (1958). Soil Chemical Analysis. Prentice Hall Eaglewood Cliffis. New Jersey. 498 pp.

Kay. S.H. and Haller. W.T. (1986). Heavy metal bioaccumulation and effects of water hyacinth weevils, Neochet- 
inc eichhornial feeding on water hyacinth. $E$. crassipes. Bull. Environ. Contamin. Toxicol. 37 : 239-245.

Kondap, S.M., Rao. Y.Y. Mirza. W.A., Rao. A.R. and Raju. K.S. (1981). Studies on the use of E. crassipes and Ipomea camea weeds as a source of green manure. In: Proceedings, 8th Asian-Pacific Weed Sci. Soc. Conference. pp. 153-155.

Little. T.M. and Hills, F.I. (1978). Statistical Methods in Agricultural Research. University of California. Davis, 242p.

Mbagwu, J.S.C (1989). Effects of organic amendments on some physical properties of a tropical Ultisol. Biol. Wastes 28: 1-13.

Mbagwu. J.S.C. (1992). Improving the productivity of a degraded Ultisol using organic and inorganic amendments. 1. Chemical properties and maize yield. Biores. Technol. 42: 149-154.

Mbagwu. J.S.C. and Abeh, G.O. (1998). Prediction of engineering properties of tropical soils using intrinsic pedological parameters. Soil Sci. 163: 93-102

Mbagwu. J.S.C. and Piccolo. A. (1990). Carbon. nitrogen and phosphorus concentrations in aggregates of organic waste-amended soils. Biol. Wastes. 31: 97-111.

Mbagwu, J.S.C., Piccolo. A. and Spallacei. P. (1991). Effects of field applications of organic wastes from different sources on chemical, meological and structural properties of some Italian surace soils. Biores. Technol. 37: 71-78.

Mbagwu, J.S.C.. Unamba-Opaath. I. and Nevo. G.O. (1994). Physico-chemical properties and productivity of two tropical soils amended with dehydrated swine waste. Biores. Technol. 49: 163-171.

Mclean. E.O. (1965). Aluminium. In: C.A. Black et al. (eds.) Methods of Soil Analysis. Part 2. Ist Ed. ASA. Madison. Wisconsin. pp. 972-986.

Obi. 1.U. (1986). Statistical Methods for Detecting Differences Between Treatment Means. SNAAP Press. Enugu, Nigeria. $45 \mathrm{p}$.

Obi. A.O. and Akinsola. A.O. (1995). The effects of lime application on the yield of tomato (Lycopersicon esculentum $\mathrm{L}$. Walp.) and chemical properties of an Iwo soil (Typic Paleustult) in southwestern Nigeria. Nig. J. Soil Sei. 11:77-87.

Obi, A.O. and Molindo, W.A. (1995). Evaluation of the nitrogen supplying potential of soybean (Glycine maxima) and its effeer on maize yield. Nig. I. Soil Sci. 11:77-87.

Rady, H.M. (1979). Dangers and utilization of the water hyacinth. Plant Res. Dev. 10:46-52.

Rosemond. J.M. Erickson. C.G. and Vann. T.K. (1984). Control of water hyacinth and water lettuce with glyphosate. In: Proceedings, Southern Weed Sci. Soc. 37th Annual Meeting: pp. 292-299.

Roy, A.K. (1979). Control of root-knot of jute with decafeinated tea waste and water hyacinth compost. Indian
Phytopatology. 32: 367-368.

Spaccint. R.. Piccolo, A., Mbagwu, J.S.C.. Zena Teshale A.. Igwe. C.A (2002) Intluence of the addition of organic residues on carbohydrates content and structural stability of some highland soils in Ethiopia. Soil Use \& Manage. 18: 404-411.

Utomo. I.H. (1981). Composting water hyacinth (E. crassipes) as fertilizer. BIOTROP (SEAMED) Regional Centre for Tropical Biology) Annual Report, Indonesia: pp. 50-51.

Venkataramanan. M.N.. Singh. H.D. and Baruah, I.N. (1984). Utilizaton of water hyacinth (Eichhornia crassipes Mart. Solms.) for biofertilization of agricultural fields. In: Proceedings of the International Conference on Water Hyacinth. Ed. Thyagarajan. G. UNEP, Nairobi, Kenya. pp. 759-769.

Walkley, A. and Black. I.A. (1934). An examination of the Degtjaref method for determining soil organic matter and a proposed modification by the chromic acid titration method. Soil Sci. 37: 29-38. 